\title{
Csillag Pál
}

\section{SEREGI '90}

\section{DOI 10.35402/kek.2021.1.6}

\begin{abstract}
Absztrakt
Kulturális örökségünk meghatározó része Seregi László életműve és alkotásai, bátran mondhatjuk, hogy az egyetemes táncművészetnek is. Idén ünnepelnénk kilencvenedik születésnapját. Róla és alkotásairól hatalmas mennyiségủ írás, kritika és vele készült interjú jelent meg. Ha csak Kaán Zsuzsa Seregi címü könyvét olvassuk, akkor is szinte teljes képet kapunk az alkotóról és műveiről. Most inkább olyan személyes történetekkel és visszaemlékezésekkel szeretnénk megismertetni a hallgatóságot, melyek talán sosem hangzottak el nyilvánosan. Volf Katalin felkérésére kerestem meg kollégákat, akiket ezekről a személyes és meghatározó pillanatokról kérdeztem. Szerencsére többen vállalták, hogy személyesen is beszélnek ezekről az emlékeikről és jelenlétükkel megtisztelik a konferenciát.
\end{abstract}

\section{Abstract}

László Seregi's oeuvre is a significant part of not just our Hungarian cultural heritage, but the universal art of dance as well. He would be 90 years old this year. There are countless writings about him and his creations, including interviews, critics and films of his choreographies. If we only look at Zsuzsa Kaán's book about him, we get nearly a complete impression of his person and creations. This time I'd prefer to share such stories and reminiscences which perhaps has never been known by the public. On the request of Katalin Volf I asked former colleagues to remember significant moments of their life connected to László Seregi. Fortunately many of them agreed to share their stories with us in person and participate in our conference.

90 éve, 1929. december 12-én született Seregi László, a magyar balett és táncélet legjelentősebb koreográfusa, rendező zsenije. Ebből az alkalomból emlékeztünk meg róla és alkotásairól a Magyar Táncművészeti Egyetem által szervezett Tánc és Kulturális Örökség - VII. Nemzetközi Tánctudományi Konferencián. A szervezőbizottság erre egy kétórás, önálló szekcióülést biztosított az Egyetem if. Nagy Zoltán színháztermében.

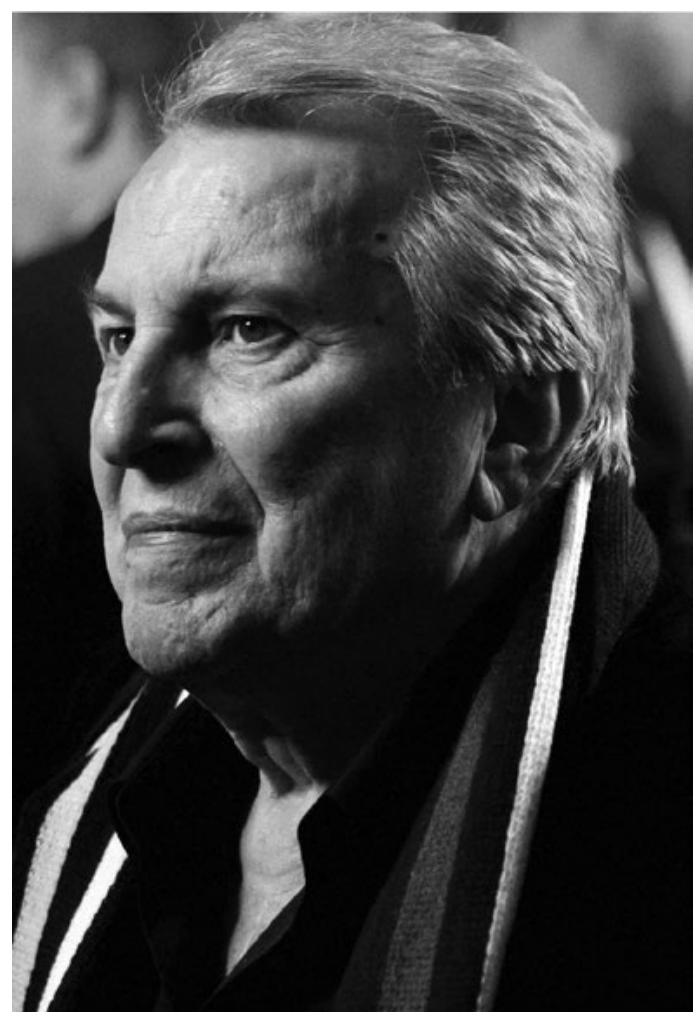

1. kép: Seregi László 2012. február 2-án, Operaház, fotó Csillag Pál

Seregi életműve és alkotásai kulturális örökségünk meghatározó része, nyugodtan mondhatjuk, hogy az egyetemes táncművészetnek is. Róla és alkotásairól számtalan írás, kritika és vele készült interjú jelent meg. Ha kizárólag csak Kaán Zsuzsa Seregi címü könyvét olvassuk el, akkor is szinte teljes, személyes vallomást kapunk róla, életéről és alkotásairól. Ezért ez alkalommal olyan történetekkel és visszaemlékezésekkel idéztük föl Seregi életét és alkotásait, melyek talán sosem hangzottak el nyilvánosan. Kortársakat és kollégákat kerestem meg, akiket életük és pályájuk Seregivel kapcsolatba hozható meghatározó pillanatairól és élményeikről kérdeztem. Sokan vállalták, hogy hosszabb-rövidebb interjú keretében mesélnek Seregiről és a hozzá 
köthető meghatározó élményeikről. Volf Katalin, Kollár Eszter és Kováts Tibor személyesen is megtisztelték konferenciánkat és osztották meg velünk emlékeiket.

Az előadásba olyan interjú-, riport- és film-részleteket is kiválasztottam, melyekben Seregi maga beszélt életéről, alkotásairól. Ezek nemcsak az elhangzó információk miatt voltak érdekesek, hanem felidézték sajátos, néha kicsit szarkasztikus humorát, öniróniáját is. Sajnos e kiadványban nincs lehetőség az előadás teljes anyagát megjelenteni, így most csak néhány rövidebb részletet idéznék az előadáson elhangzottakból.

Seregi első színházi élményéről beszélt egy 1995 ös interjúban, melyet Schäeffer Erzsébet készített:

„A Visi Imre utcából is el lehetett keveredni valamerre. Látja drágám, így. Oldalról, borzalmas kínok közt. Amit tudok, az gyüjteménye mindannak, amit nem tanítanak. Ez lehet, hogy nagyképüen hangzik, de így van. Kissrác korom óta vonz a müvészet. Kórházról kórházra vándorló, vérszegény, beteges gyerek voltam. Rettenetesen érzékeny, szenzitív alkat. Pontosan emlékszem, amikor anyám először vitt színházba a Kálvária térre. Megigézve ültem a nézőtéren, és néztem a függöny két oldalán az aranyozott kis stukkón az ornamentikát. Néztem, figyeltem, és egy idő után, kicsit csalódottan megkérdeztem anyámtól, hogy hát ez a színház? Nagyon kicsi lehettem, ha ilyen hülyeséget kérdeztem. Anyám akkor azt mondta, várjál Lacika, ez a függöny, majd, ami mögötte van, az lesz a színház. És úgy is lett”.

Egy volt kolléga a feszített próbaidőszakhoz, Seregi stílusához és személyiségéhez kapcsolódóan a következőket mondta:

„Akkor még volt szakszervezet. Az egyik szakszervezeti értekezleten fölállt a legjobb barátja Zilahy Győzö, és azt mondta: - Laci, ha nem lennél ilyen rohadt tehetséges, már rég az utcasarkon megvertünk volna. - Ezt nagyon kevesen merik elmondani. De nem ez volt a jellemző. Mindnyájan inkább a szépre emlékezünk".

A fából faragott királyfi kapcsán Kováts Tibor így mesélt az emlékeiről:

„A fából faragottra festettek a sminkben. Laci bejött, megnézte, ahogy ügyeskedtek, próbálták a fabáb arcot megfesteni. Aztán azt mondta na jó, ezt felejtsük el, ez úgy rossz, ahogy van. Leült elém, belenyúlt a barna festékbe az ujjával és húzott egy csíkot itt, majd ott, aztán nagy ecsetvonásokkal meghúzta a szememet, mint egy szoborét. Öt perc alatt felrakta a sminket a fejemre és a testemre, ami kilátszott, mint egy vászonra. A sminkesek és fodrászok csak álltak és nézték a rusztikus vonalakat, amikből egyértelműen kiderült, hogy ki ez a figura. A robosztussága, ami a koreográfiájában is benne van, ahogy élettel telik meg az élettelen merevségből. Olyan sminkmesteri kurzust tartott három perc alatt, hogy mindenki elfehéredett. Ez a smink nekem is egy fontos adalék volt a karakterhez, ahhoz, hogy hogyan kell nekem ezt a figurát eljátszanom, jobban visszaadnom azt, ami Laci szándéka, elképzelése volt ezzel a szereppel kapcsolatban. Laci talán ezt tudta legjobban, a lényeget megmutatni.

Egy másik történetem is van a fábólfaragottról. Meghívták Firenzébe betanítani a darabot. A Milloss-féle Mandarinnal együtt játszották.

Akkor még ORI időszak volt, vasfüggöny lent, az ORI-n keresztül lehetett csak utazni. Egyszer csak behívtak az ORI-ba, hogy a Laci küldött egy könnycseppekkel átitatott levelet, szinte könyörgött, hogy menjek ki, mert az a táncos, aki a fabábot kellett volna táncolja, nem fogja tudni eltáncolni. Kiengedtek, kiutaztam hozzá, elkezdtünk próbálni, nagyon helyes volt, sokat voltunk együtt, mi ketten voltunk csak magyarok. Egy kis motelben laktunk. Firenze az ő világa volt. Sokat sétáltunk, néztük az épületeket, mindenről eszébejutott valami. Állandóan át akart adni valamit.

Csodálatos időszakot tölthettem el vele. Olyan szerepeket táncolhattam, mint például a Szentivánéji álom Puck-ja, amiről mondhatom, hogy rám készítette. Nagyszerű szerep volt, imádtam. A Rómeóban a bohóc is rám készült, ami szintén egy hatalmas élmény volt. Rengeteg szerepet köszönhettem neki. Vele a munka nem úgy nézett ki, mint más koreográfusnál, hogy a te személyed kimarad belőle. Ő táplálkozott belőled, az éppen aktuális táncosból. Nem úgy tekintett rád, mint eszközre, hogy ő kitalálja a lépéseket és betanítja, a táncos pedig eltáncolja. Igaz, hogy nagyon pontos elképzelése volt mindenről, de a táncos személyiségéhez alakította a szerepeket. Ez később is így volt, mikor valaki új állt be egy-egy szerepbe, akkor is igyekezett annak a személyiségét vagy éppen a különbözőségét kiaknázni, ezeket beépíteni. Szívesen igazította a szerepeket az aktuális táncosára. Úgy éreztem, volt köztünk egy jó együtt-játszás. Szerette a kicsit bohóc, kicsit virtuóz, játékra nyitott karaktaremet. Mind a mai napig nagyon szeretek játszani. Az egész táncos pályámat úgy éltem le, 
hogy egy nagy játék volt. Egy pillanatát nem éreztem munkának, vagy megterhelőnek. Játszottam, amivel csak tudtam, annak ellenére, hogy nagyon fárasztó szerepeket táncoltam. De ezeket tudtam önfeledten élvezni és ebben a Laci nagyon jó partner volt. A játékra mindig vevő volt. Az pedig egy igazi csoda volt, hogy mennyi mindent kaptál tőle szakmailag. Nagyon sok helyen táncoltam, sok emberrel dolgoztam együtt, de olyan összetett dolgokat a művészetről, vagy erről a pályáról senkitől sem kaptam, mint tőle. Nem csak azt, hogy mi a balett és szakmai kérdéseket, hanem az egész viszonyrendszert a színpaddal, a te karaktereddel, a szereppel, a dramaturgiával, a szándékkal. Laci egy nagy reneszánsz figura volt, aki mindenhez értett, mindenben benne volt, mindenben tehetséges volt. Ezt az egészet összegezte és át is tudta adni. Ehhez az is kellett, hogy volt egy csodálatos betanító balettmestere, Kaszás Ildi, aki minden lépést és mozdulatot tudott, aztán amikor a Lacival dolgoztál és hagytad, akkor megemelt tíz emelet magasra, a gondolataival, a szellemiségével, a humorával. Ha a játékban társa voltál, akkor ebben tudtál lubickolni, és ennél nagyobb öröm nincs. Ilyen alkotóból nagyon kevés van ma már. Nagyon szerencsés voltam, hogy ezt a korszakot élhettem meg, és együtt dolgozhattam vele. A legjobb élményeim és a legnagyobb negatív élményeim is hozzá kötődnek. Nem titkolom, hogy volt olyan levélváltásunk, amiben visszaadtam vagy lemondtam szerepet, mert nagyon megbántott. Ö ebben is különleges volt. Nagyon meg tudott bántani és szeretni is embereket. Sokat tudott adni és nagyon sokat elvenni. Valószínűleg ezt többen is el tudnák mondani. Sok embert megbántott, hozott olyan helyzetbe, ami méltatlan volt. Voltak nagyon nehéz pillanatok. Az érdekes az, hogy mindezektől függetlenül mindig mindenki, én magam is túltettem magam ezeken. Mert egy géniusz volt, és ez felülírt mindent. Általa egy olyan minőséggel voltál összezárva, ami mindenért kárpótolt, minden mást elfeledtetett a tehetsége. És frenetikus humora volt, ezt mindenki tudta. A hibáival és a gyarlóságával is tisztában volt. Nagyon fontos volt neki a siker. Az, hogy amit ő csinál jelentős legyen és értékeljék. Azt gondolnánk, hogy egy ilyen sikeres és elismert müvész magabiztos. Valójában ez is áradt belőle, pedig nem volt az. Mindig mindenben bizonytalan volt. Mindent megkérdőjelezett magával kapcsolatban. Folyamatosan gyötörte magát, hogy jó-e, amit csinál, tényleg elég tehetséges-e. Tele volt bizonytansággal, kétségbevonta a saját képességeit. Talán ez vitte őt előre is, ezért tudott egyre jobb darabokat csinálni. Nagyon fontos volt számára, hogy ki mit mond és hogyan. Ezekből tudott építkezni, táplálkozni. Minden pillantás, rezdülés, egy-egy ember véleménye annyira fontos volt számára, hogy nem is gondolnánk.

Akikkel dolgozott, azokban semmit nem hagyott benne. Ha meglátott valakiben valamit, azt kiszedte. Amit elképzelt, azt meg tudta mutatni a müvészeken keresztül. Az egyik legjobb példa Volf Kati a Rómeó és Júliában. Kati csodálatos táncosnő volt már 18 éves korában. De olyan volt, mintha minden belső érzelme egy fal mögött játszódott volna le benne, és nem tudott kijönni. Én még ilyet nem láttam, hogy egy művésznek ekkora tudása legyen bezárva. A Laci addig gyötörte, amíg ez a fal le nem omlott, és ki nem ömlött mögüle, mint az árvíz. Abban a pillanatban Katiból megszületett egy olyan formátumú müvész, amilyen nagyon kevés van. Ebben Lacinak hatalmas szerepe volt. Kati mủvészetén is lehet látni azt az arányosságot, amit a Laci szintén nagyon fontosnak tartott és fantasztikusan érzett. Szerette a harsány dolgokat, de annak is arányosnak és ízlésesnek kellett lennie. Ízlés, stílus, ritmus és dinamika specialista volt. Összetett dolgot tudott és adott át. A darabjain is ez látszik. A Sylvia például. Egyszerre humoros, elnagyolt és míves, szívbemarkoló, nagyszerű figurákkal, karakterekkel. Ha jól bele tudtál bújni a szerepbe, fantasztikus komfortos érzésed volt. Élmény ezeket a darabokat táncolni és nem mellesleg igényes tánctechnikai feladatod is van. Vannak olyan koreográfiák, ahol nagyon erős a karakter, de nincs feladatod a lábaddal, a testeddel. Vagy fordítva, nagyon nagy a feladat technikailag, de nem szól semmiről. Lacinál ezek csodálatosan arányosak voltak. Nagyon sajnálom, hogy az a tudás, ami benne volt, vele együtt távozott. Nem volt lehetősége továbbadni. Nem gondolkodott azon, hogy valakit kineveljen, megpróbálja átadni neki a tudását. Nem adta át a stafétát. Ez nem csak az ő hibája volt, a környezeté is. Ez egy hatalmas veszteség. Az ő tudását valahogy tovább kellett volna vinni. A tudást, látásmódot, gondolkodást, ami benne összpontosult. Lehet, hogy ő nem akarta, de az is lehet, hogy nekünk kellett volna provokálnunk. Laci elment, minden megszakadt, csak a művei maradtak. Reméljük, hogy mind a Harangozó-, mind a Seregi-életmü fennmarad. Kevesen tudnak úgy történetet mesélni, mint ö tudott.

Nagyon sok helyen betanította a darabjait, de a Magyar Állami Operaház tudta a műveit a legjobban interpretálni. Mert itt volt meg az a kultúra, 
hagyomány, az iskola, ami ehhez kellett. Máshol hiába voltak kiváló táncosok, de a szaga, ahogy Laci fogalmazott, az nem volt olyan, ahogy mi tudtuk megcsinálni. Ezt kellene megtartanunk. Ez különböztetett meg bennünket mindenki mástól, ebben vagyunk nagyon jók. Amikor embereket kell magrajzolni, történeteket kell elmesélni. A lényeg ez. Akik ezzel együtt nőhettek fel, ebben részesek lehettek azoknak megadatott az a csodálatos élmény, hogy leült egy előadás után úgy érezte, hogy valamit letett az asztalra. Az ötödik pozíció, a battement tendu és a tour en l'air kevés, az nem elég.

Nagyon emberközeli darabokat csinált. Fontosak voltak neki az emberek, belőlük táplálkozott. Karaktareket, életeket, vérbő sztorikat vitt színpadra és ez nagyon kell. Nem véletlenül vonzódott a Shakespeare-művekhez, a nagy történeteket elmesélő művekhez. Manapság nagyon kevesen mernek vagy tudnak ilyen történeteket elmesélni a színpadon. Laci ezekkel tudott bánni, tudta, mit és hogyan akar elmondani, mi az üzenete. Nagyszerü stílusérzéke volt. Tőle stílust tanultál minden pillanatban. A hamisságot, a stílus nélküliséget, az igaztalan dolgokat egy pillanat alatt kiütötte belőled, mint egy defibrillátor. Aki képes volt erre, azokkal tudott együttmüködni. Viszont nem szerette a mübalhét. Az őszinte, kristálytiszta, de nagyon egyszerủ mozdulatokat, előadásmódot szerette. Mindezt úgy csinálta, hogy nem filozofálta túl. Nem éreztem azt, hogy itt most jön egy nagyon okos ember, iszonyatos intellektussal, hanem megmaradt embernek és az egész stratégiája vagy technikája, amivel téged helyzetbe hozott, spontán alakult ki. Ha kellően nyitott voltál, nem azt érezted, hogy itt van egy nagy tanító a saját intellektusával, te pedig ültél, hallgattad, próbáltál közelebb kerülni hozzá, hanem az egész nagyon könnyedén áramlott. Csak azt vetted észre, hogy egyszer csak hopp, bepattant a testedbe, a mozdulatodba, a művészetedbe az ő tehetsége. Ezt nagyon nehéz megcsinálni, mert az ember önkéntelenül is a saját értelmével van elfoglalva. Laci nem csak a koreográfiáiban volt virtuóz, a verbális kifejezőkészsége, mondatai is ugyanolyan virtuózak voltak. Nem elsősorban a gyorsaságra gondolok, hanem arra, hogy az ő intellektusa a táncában is megjelent. A táncában is ugyanolyan játékos és gondolkodó volt. Mindig nagyon fontos volt számára a tér, a ritmus, a vizualitás".

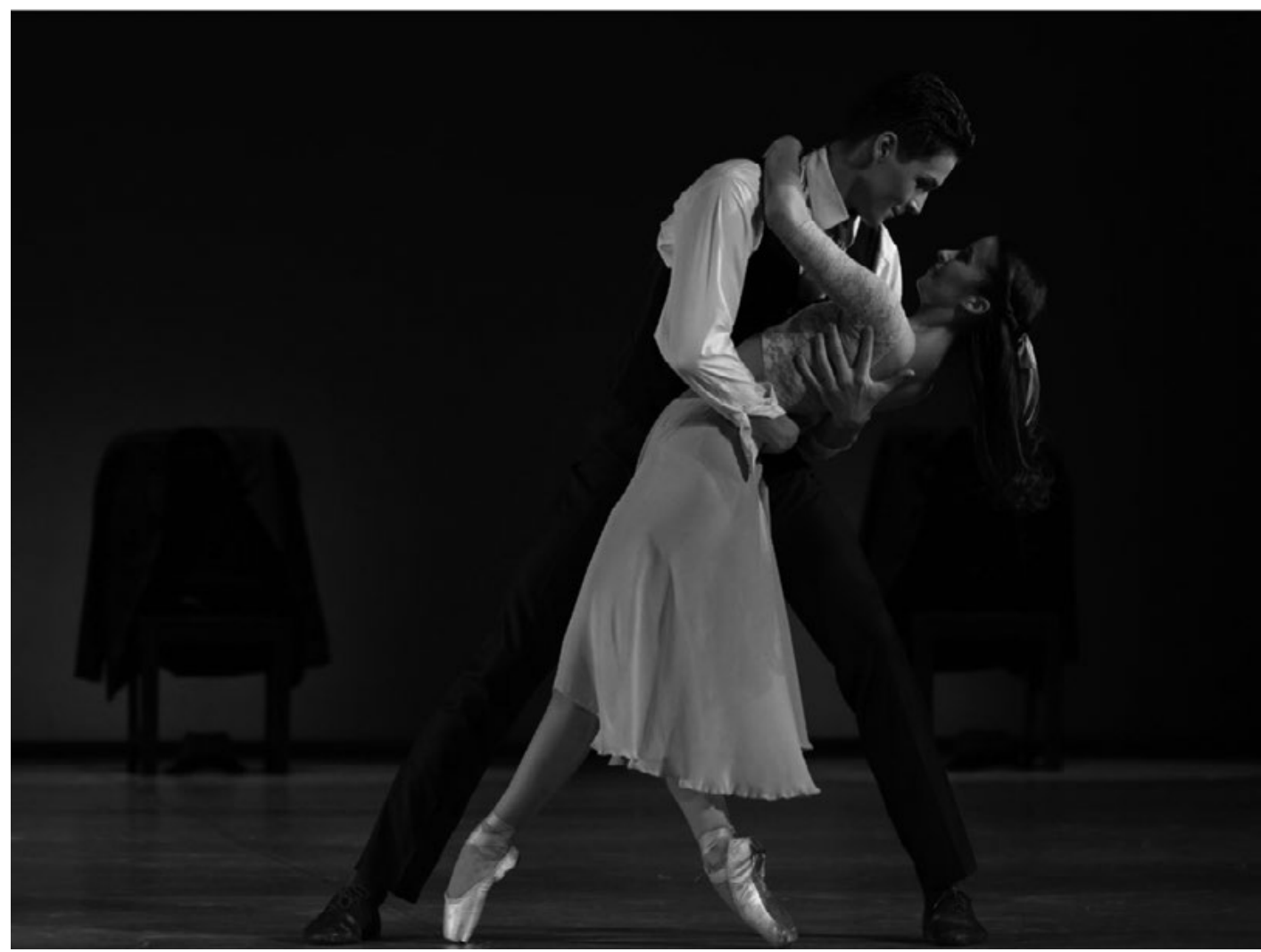

2. kép: Dohnányi Ernö - Seregi László: Változatok egy gyermekdalra, Kóbor Demeter és Guti Gerda az MTE végzös hallgatói, fotó: Csillag Pál 
1975-ben készült A cédrus című koreográfia. 1976-ban film-adaptáció is készült a müről, melyet stúdióban forgattak, nem színházi előadásról készült a felvétel. Mint Seregi többi művét, ezt is Horváth Ádám rendezte. Kollár Esztert kértem, hogy meséljen a forgatásról, Seregi és Horváth Ádám együttműködéséről, kapcsolatukról.

„Annak ellenére, hogy barátok voltak, Laci és Ádám között nagyon nagy harc volt. Két erős egyéniség, akik a saját elképzelésüket akarták megmutatni, elővarázsolni. Más-más beállításokat szerettek volna használni. Ádám azt mondta üvöltve: Én vagyok a film rendezője! - mire Laci mindig azzal válaszolt, hogy De én vagyok a koreográfusa! Ebből őrületes viták alakultak ki. Aztán valahogy mindig megegyeztek és végül egy nagyon szép film készült A cédrusból. Nagy kaland volt”.

Az alkotó Seregiről pedig így emlékezett:

„Laci nagyon szenvedő alkotó volt. Soha nem magától koreografált. Mindig megrendelésre dolgozott. Ez sok kötöttséggel járt, megmondták, miből és mit kell létrehozzon. Ezt aztán el tudta engedni. Laci mindig mindenből felkészült, mindenre odafigyelt. A díszletekre, a jelmezekre is különös gondot fordított, az ő megérzései és elképzelései alapján készültek. Mindent nagyon pontosan, jó stílussal tudott az adott korba helyezni.

Mindig bizonytalan volt, annak ellenére, hogy mást mutatott a teremben, a barátaival, mindenütt. Senki nem tudta, hogy milyen kishitű és bizonytalan abban, hogy jó lesz-e amit csinál, kell-e majd a közönségnek. Ez egy nagyon érdekes kettősség volt benne. De amikor a munka zajlott, nem kételkedett, csak amikor már állt a kész díszlet, a jelmezek is elkészültek és a jeleneteket kezdtük egymás után összefüzni. Amikor elöször lement egy színpadi próba, újra azon gondolkodott, hogy jó lesz-e így, nem kell-e valamin változtatni. Majdnem minden darabját megszenvedte. Az infarktusok, amik gyarapodtak az ő kis szívén, azok jogosak voltak”.

\section{Szakály György emlékei:}

„A Macskáknál és a Rómeónál is azt érezte az ember menet közben, ahogy készült a darab, hogy ez csak siker lehet. Mindenki szagot kapott a városban. A Nemzeti Színház színészei jártak át nézni a próbákat, amikor már lehetett, mert a színpadon próbáltunk. A Madách Színház is ott volt a nézőtéren. Pedig akkor még nem volt közösségi média és mobiltelefon. Szóltak egymásnak az emberek. Kétségtelen, hogy nagyon művelt, olvasott és tájékozott ember volt. Nem tudom, hogy volt ennyi energiája. Mindenevő volt. Irodalom, művészet, művészettörténet, filmek, mindenben naprakész volt. Viszont érezhetően volt benne egy bizonyos kisebbrendüségi érzés, mert soha nem volt balettos. Ezért is ragaszkodott nagyon Kaszás Ildihez. Nagyszerűen tudtak együtt dolgozni. A sors érdekessége, hogy amikor igazgató lettem, hivatalosan én voltam a fönöke. Az öreg Harangozón és Seregin kívül nincs olyan koreográfus, aki ilyen örök érvényű darabokat készített volna. Függetlenül attól, hogy nem a szó szoros értelmében vett klasszikus baletteket állított színpadra. Nagyon tudta, mi kell a magyar közönségnek, és általában a közönségnek. Minden darabja a mi sajátunk, sehol a világon nincs olyan előadási mód, ahogy a Laci akarta. A 90-es évek elején Kanadába vittük a Szentivánéjit. Az első előadás még foghíjas volt, de másodra és az összes többire már nem lehetett jegyet kapni. Az írták róla, hogy ez nem balett, hanem egy fantasztikus hollywood-i show. A Laci erre azt mondta, hogy igen, az volt a célom. Egy olyan együttes van, ami ezeket a darabokat jól elő tudja adni: a Magyar Nemzeti Balett, az Operaház balettegyüttese. Kutya kötelesség lenne ezt az örökséget ápolni. Ma nincs a helyén kezelve, az nagyon szomorú, és független attól, hogy szeretett, nem szeretett, néha elviselhetetlen volt, máskor pedig egy bủbáj”.

Volf Katalin a Rómeó és Júlia kapcsán emlékezett vissza:

„Lacival rengeteg élményem volt. Az egyik, ami nagyon mélyen megmaradt bennem, amikor a fópróbák felé haladtunk a Rómeóval. Az egyik jelmezes színpadi próbán a méregivás jelenetnél tartottunk. Laci egyszer csak leállította próbát és elindult fölfele a színpadra. Megállt a levegő a színházban, mert megszoktuk, hogy mindig, hangosan, üvöltve mondja az instrukcióit. Teljes csönd lett. Mindenki állt a színpadon, a kulisszákban, egy pisszenést sem lehetett hallani. Én ott térdeltem a ruha elött az üveggel a kezemben. Odajött, leguggolt mellém és egészen intimen, mint egy titkot, halkan elmondta, a fülembe súgta, hogy mit csináljak, hogy ő hogy szeretné. Miért úgy kell megfogni az üveget, miért emeljem oda a könyökömet, és hogy nyelnem kell, mutassam az arcomat is. Látnia kell ott fönt is mindenkinek azt az apró üveget. Majd felállt, ott hagyott, visszament a nézőtérre és folytattuk a próbát. Ez egy csodás pillanat volt. És egyáltalán nem volt jellemző Lacira, nem szokott elöfordulni, hogy ennyire meghitten mondjon el valamit. Amikor 
kiabált, azt sem vettem tőle rossz néven. Mindig tudtam, hogy azért teszi, mert a legjobbat akarja az emberből kihozni, nem öncélúan a saját hatalmát akarja gyakorolni, hanem hogy a másikból minden áron kihozza azt az ezer százalékot, amit látni akart. Ha belépett a terembe megsokszorozódott az ember ereje, más közegbe kerültél. Persze volt kiabálás, sírás, dicséret, de minden azért volt, hogy belőled a legjobbat hozza ki és az szülessen meg a te testeden, amit ő elképzelt és látni akart. Annyira jó volt ôt ámulatba ejteni, olyan boldog volt az ember, amikor a Laci örült annak, ami jó volt és megdicsért, sikerélményt tudtál neki adni. Jobban örültem annak, hogy a Seregi boldog, mint, hogy én ügyes voltam. Az igazi kihívás nekem az volt, hogy jobb legyek, mint amit ő elképzelt. Ezt értékelte is.
Nagyon jó érzés volt akármilyen kis dolgot is hozzátenni ahhoz, amit ő akart. Egy másik elképesztő történet az volt, amikor kitalálta, hogy a kriptajelenetnél a Rómeó végigcipel a lépcsőn, mint egy hullazsákot. Felvitt minket a festőterembe, mert ott volt egy hatalmas meredek lépcső. Mindenki odagyült, a festők is csak néztek, hogy mit csinálunk ott. Persze az egész színház készült már a Rómeóra és Seregit amúgy is imádta mindenki. Azon a lépcsőn találta ki pontosan, a festők előtt, hogy hogy fogjuk egymást, mi hogyan történjen. Halálfélelmem volt fejjel lefelé lógva, ő meg röhögött, de teljes izgalomban volt, látni akarta maga előtt, hogy az tényleg egy hulla, akinek persze végig aktívan kell segíteni, hogy múködjön a jelenet.

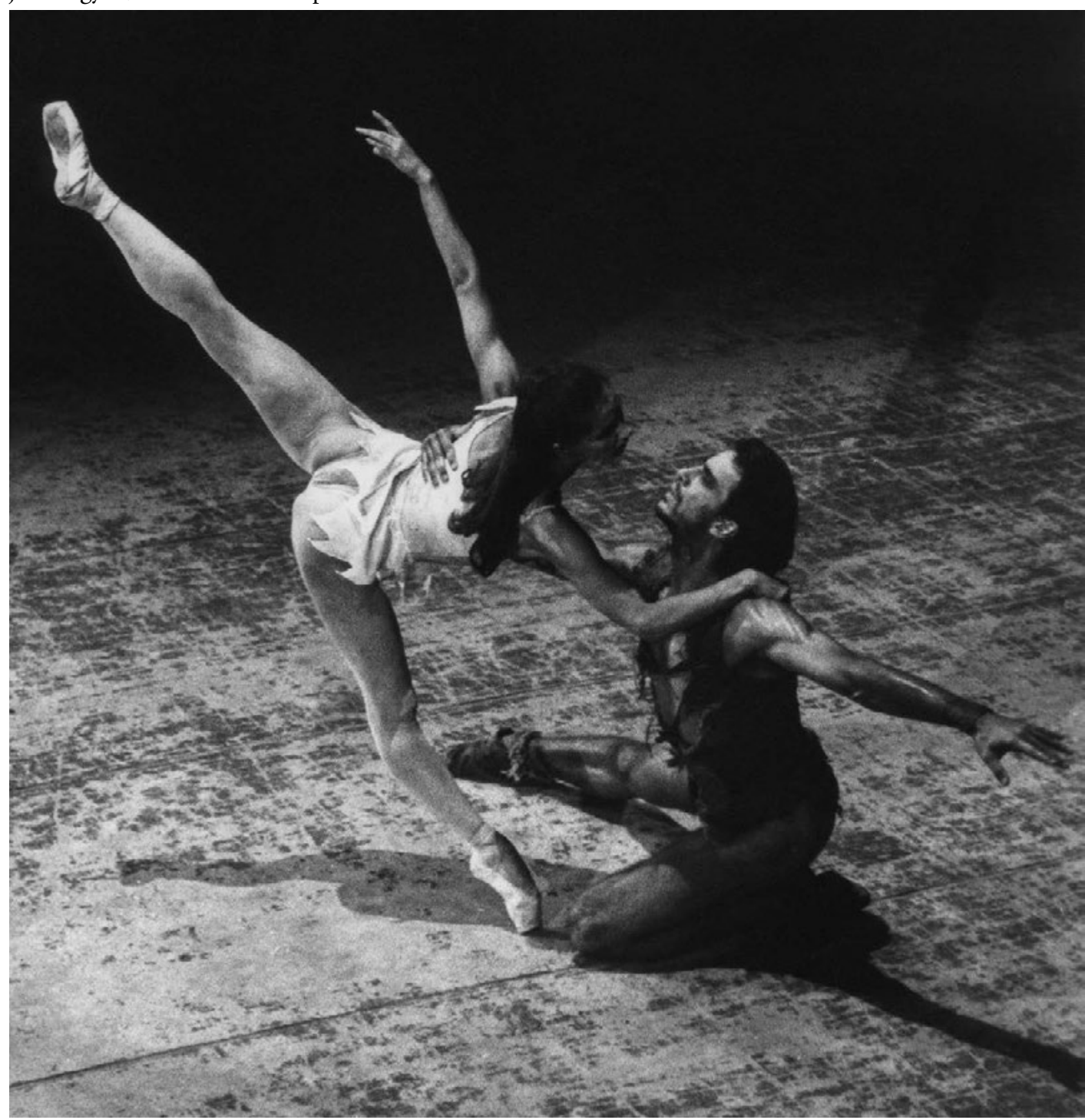

3. kép: Volf Katalin és Solymosi Zoltán Hacsaturján - Seregi László Spartacus címü müvében, Operaház, fotó Csillag Pál 
Nagyon-nagyon jó ízlése volt. Soha nem fogott mellé senkivel. Ha esetleg valakinek a figurája vagy szerepformálása nem is találkozott az ő elképzelésével, mondjuk úgy gondolta, hogy én nem lehetek Flavia, mert ő nem ilyennek képzelte el, akkor valahogy olyanná formálta, illetve hagyta, hogy magadra alakítsd - természetesen az ő elképzelésének megfelelően. Nem akart ugyanolyat látni mindig. Csak segített a karakterhez. Ami esetleg hiányzott belőled, azt ő próbálta előhozni, erősíteni. Ezért őt is érhette néha meglepetés. Emlékszem, egyetlen szerep volt az életemben, amit elkértem: az a Titánia volt a Szentivánéji álomban. Eredetileg a négy párba akart minket betenni Zolcsival (ifj. Nagy Zoltán), de akkor Amerikában voltunk és nem tudott ránk várni, így másokkal kezdett el próbálni. Ezért nagyon haragudtunk - föleg mikor megnéztük a bemutatót, de természetes volt, hogy ha premierre készül valaki, nem lehet, hogy egy hónapig nincs itthon. Később egyszer csak vettem a bátorságot, és bementem az akkori igazgatóhoz, Keveházi Gáborhoz, és megkértem, hogy ha Laci is megengedi, betanulnám Titánia szerepét. Leginkább a második felvonás pas de deux-jébe szerettem bele. A Laci válasza annyi volt, hogy „rendben”. Én teljesen más karakter voltam, mint amilyet ő kitalált. Az is jellemző volt Lacira, hogy elöször nem szeretett több szereposztással bíbelődni, egyben gondolkodott. Később, mikor Kanadában voltunk turnén a darabbal, a második felvonás után ültem az öltözőben. Egyszer csak Seregi feltépte az ajtót, berontott, eufórikus állapotban a nyakamba borult, és az egekig magasztalt, mert azt a hangulatot, azt a pillanatot, amit ő megálmodott és elképzelt, azt kapta vissza tőlem a színpadon. Ez egy nagyon nagy dicséret volt. És megerősített abban, hogy jól éreztem, hogy be kell kopognom ezért a szerepért".

Keveházi Gábor így emlékezett vissza Seregire: „A Laci egy óriási művész volt. Az alkotásai 30 éven keresztül határozták meg a magyar nemzeti balett arculatát, és nagyon nagy kár, hogy most nem tartják műsoron ezeket a csodálatos műveket. Kellene játszani kettőt-hármat minden évadban a darabjaiból. Azt merem mondani, hogy ő volt a huszadik század legjobb balett rendezője. Szándékosan nem koreográfust mondtam. Az, hogy valaki balettet ilyen tökéletes dramaturgiával tudjon rendezni, az nagyon ritka. A lépésanyaga neoklasszikus, maga az alkotás, a végeredmény pedig zseniális. Nem véletlenül járta be a világot. Nem csak Magyarországon volt sikeres, nemzetközileg is".
Ezúton írásban is szeretném újra megköszönni a kollégák lelkes és segítőkész hozzáállását az interjúk elkészítéséhez. A beszélgetések közben még világosabbá vált, amit eddig is tudtunk, hogy Seregi személyisége és teljes életműve további kutatást és adatgyüjtést kíván, hogy még teljesebb képet kapjunk róla, amit kötelességünk megőrizni, és mindazok számára is elérhetővé tenni, akik nem ismerték őt személyesen, vagy dolgoztak vele együtt.

\section{Források}

Schaeffer Erzsébet: Egyszer volt történetek, találkozások. Nők Lapja mủhely, Sanoma Budapest Kiadó Rt., ISBN 9632124634

Kaán Zsuzsa: Seregi. Készült a Nemzetközi Táncés Kultúra Alapítvány, Trionfo Ktf. Közös kiadásában.

\section{Képek}

Seregi László 2012. február 2-án, Operaház, @fotó Csillag Pál

Volf Katalin és Solymosi Zoltán Hacsaturián - Seregi László Spartacus című művében, Operaház, (Ofotó Csillag Pál

Dohnányi Ernő - Seregi László: Változatok egy gyermekdalra. Kóbor Demeter és Guti Gerda az MTE végzős hallgatói, Ofotó Csillag Pál 